\title{
SUSTAINABLE MANAGEMENT OF MINERAL RESOURCES IN THE CONTEXT OF JSC "LATVIA'S STATE FORESTS" CIRCULAR ECONOMY
}

Andrejs Lazdins ${ }^{1}$, assist. professor, Dr.oec.; Liga Jankova ${ }^{2}$, assist. professor, Dr oec. and Anita Auzina ${ }^{3}$, assoc. professor, Dr.oec.

1,2,3 Latvia University of Life Sciences and Technologies

\begin{abstract}
Sustainability of mineral resource is linked with governing the reciprocity of economic, environmental and social processes in which the economic interests need to be made compatible with the other processes. Sustainable management of mineral resources needs to be linked with the notions of ecology and circular economy in which an opinion exists that depletion of mineral resources by itself undermines economic growth and determines the need for the most efficient ways of using natural resources in business so that maintaining natural systems could support human life and welfare also in the future. JSC "LATVIA'S STATE FORESTS" manages state owned land covering the area of 1.62 million hectares, including 1.60 million hectares of forest land, out of which 1.39 million hectares are covered by forests. Since 2002, JSC "LATVIA'S STATE FORESTS" has built forest roads (FR) in the length of approximately 5.6 thous. $\mathrm{km}$ and as of January 2018 the total length of FR had reached 11.8 thous. $\mathrm{km}$. Extraction of mineral resources and their use in building, repairing and maintaining forest roads is the company's investment in the future, as well as it makes easier the management and monitoring of forest territories, output of forests, accessibility of forests and improves the forest landscape. The research problem addresses the question whether the use of mineral resources is linked with economic benefits, whether with the growth of the company's profit the volume of extraction of mineral resources also increases. Evaluating the comparative indicators, it can be observed that the extraction of mineral resources is not closely correlated with other economic indicators - extraction and use of resources do not impact directly on the final result of the company's operations - acquiring profit. However, in the case of JSC "LATVIA'S STATE FORESTS" the problem is related with the places where mineral resources are extracted - on average about $8 \%$ of the mineral resources are extracted in new, partly researched deposits. Such an activity is legal, but it is not sustainable and does not correspond to the sustainable strategy of the European Union, nor the one of Latvia.
\end{abstract}

Key words: sustainability, mineral resources, circular economy.

JEL code: Q01; Q32.

\section{Introduction}

The use of mineral resources in relation with economic benefits regarding whether when the company's profit grows, the volume of extraction of mineral resources increases and whether the principle of sustainable management of mineral resources - sand and gravel - is followed in the extraction process is still little researched in Latvia. Research hypothesis - when building the forest infrastructure, JSC "LATVIA'S STATE FORESTS" practise principles of sustainable management of mineral resources. Research goal - to analyse the experience of sustainable management of mineral resources in JSC "LATVIA'S STATE FORESTS" in the context of circular economy. Research

tasks: 1 . to collect information on theoretical aspects on sustainable management in the context of mineral resources. 2. to perform data analysis in JSC "LATVIA'S STATE FORESTS" (LSF) on the connection between building the forest infrastructure with the profit indicators of the company and principles of sustainable management of mineral resources. Research methods: content analysis of literature and internet sources was performed to prepare the research paper, the selected data were processed and interpreted applying statistical data processing and interpretation methods. The analysed period was from 2006 till 2017. Research innovation - up to now the analysis of the results of sustainable management of mineral resources had not been conducted in JSC "LATVIA'S STATE FORESTS". Publicly available information about the performance indicators of JSC "LATVIA'S STATE FORESTS" and data of the Latvian Environment, Geology and Meteorology Centre (LEGMC) were used in the research. 
Source: created by authors, The Brundtland Report, 1987

Fig. 1. The three overlapping elements of sustainability

Sustainability is mentioned first in the UNO Brundtland report as a necessity to develop balanced use of non-renewable natural resources, not endangering natural systems that ensure life. Sustainability is explained as interaction of three E elements - environment, economy, equity - upon the condition that sustainable economic growth and development is possible when preserving the environment and acting in equitably (The Brundtland Report, 1987).

Having collected various theoretical definitions of sustainability and its influencing factors, the following statements can be highlighted:

- Sustainability is connected with the function of social and political values and knowledge that determines human behaviour (Robinson et al, 1990);

- Sustainability is defined as "sustainable use of biological resources", "sustainable agriculture” , "capacity", "sustainable energy", "sustainable society and sustainable economy" and "attainable development" (Portney, 2015);

- Sustainability is linked with consumption, which creates a link between the economic development and the degradation of the environment. Different level governments and countries' policies should be involved in ensuring sustainability (Portney, 2015);

- Brown et al. (1987) relate sustainability to the rate of tree output so that the growth of a forest would be balanced, as well as forest management and development of the infrastructure should be considered higher level social and cultural needs, such as the aesthetic values of a forest.

Table 1

\section{A summary of the foundation and definitions of sustainability}

\begin{tabular}{|c|c|c|}
\hline $\begin{array}{l}\text { Six roots of } \\
\text { sustainability }\end{array}$ & $\begin{array}{c}\text { Six definitions } \\
\text { of } \\
\text { sustainability }\end{array}$ & Points of emphasis \\
\hline Ecological & $\begin{array}{l}\text { Movement } \\
\text { capability }\end{array}$ & $\begin{array}{l}\text { Maintaining nature systems so that they could support } \\
\text { human life and welfare }\end{array}$ \\
\hline Resources/environment & $\begin{array}{l}\text { Sustainable use } \\
\text { of biological } \\
\text { resources }\end{array}$ & $\begin{array}{l}\text { Facilitating economic growth only in such a scope and } \\
\text { manner that does not cause worsening of nature systems }\end{array}$ \\
\hline Biosphere & $\begin{array}{l}\text { Sustainable } \\
\text { agriculture }\end{array}$ & $\begin{array}{l}\text { Relations between the human impact on the health of the } \\
\text { Earth and its ability to support human population }\end{array}$ \\
\hline Technology criticism & $\begin{array}{l}\text { Sustainable } \\
\text { energy }\end{array}$ & $\begin{array}{l}\text { Refusing from the opinion that science and technology } \\
\text { themselves will protect and save the Earth }\end{array}$ \\
\hline $\begin{array}{l}\text { No growth - slow } \\
\text { growth }\end{array}$ & $\begin{array}{l}\text { Sustainable } \\
\text { society and } \\
\text { economy }\end{array}$ & $\begin{array}{l}\text { Restrictions regarding the capability of the Earth to support } \\
\text { increasing human health and welfare }\end{array}$ \\
\hline Ecological development & $\begin{array}{l}\text { Sustainable } \\
\text { development }\end{array}$ & $\begin{array}{l}\text { Adjusting business and economic development activities to } \\
\text { the reality of natural resource and environment limitations }\end{array}$ \\
\hline
\end{tabular}

Source: created by authors B. Brown et al., 1987 and C. Kidd, 1992 
B. Brown et al. (1987) and C. Kidd (1992) (see Table 1) developed ideas and highlighted the intellectual bases of sustainability, in which six meanings merge around two main aspects: ecology and those that highlight economy.

Gathering opinions, it is possible to find differences between general and sustainable economy general economy concerns promoting the increase of goods and services while sustainable economic development is about developing an understanding about the impact of the increase of desires on the ability of the future generations to improve their welfare.

Within the framework of sustainable development, the European Union (EU) provides a wide policy system to satisfy the current needs, not endangering the ability of future generations to satisfy their needs. Four mutually related pillars are determined to attain the goals: economy, social, environmental and world level governance. The priority areas of sustainable development are: climate changes, transportation, types of manufacturing and consumption, managing natural resources, public health, social exclusion and poverty and fight with global poverty (European Commission, 2004).

\section{Research results and discussion}

Sustainable development of Latvia is mentioned in the document "Latvia 2030", whose basic idea is to satisfy the needs of the present generation balancing the interests of public welfare, environment and economic development, simultaneously also ensuring that environmental requirements are observed and the nature diversity is preserved not to reduce the opportunities of satisfying the needs of future generations. In the chapter "Sustainable Management of Nature Values and Services" the following are determined: Nature capital - non-renewable natural resources: minerals - sand and gravel, renewable natural resources - land, wood, energy a.o. To manage the nature capital effectively, it is necessary to determine the critical nature capital whose reduction is not to be allowed, and the objectives and indicators of preserving and renewing the nature capital. Therefore, a comprehensive analysis of the lack of nature capital in Latvia should be performed, which would compare the current situation with its reporting or benchmark level. As a result of such analysis, long-term requirements regarding sustainable management of resources for various biotypes and the areas they need could be set, evaluating which ecosystems need protection, which - active management and which require the restauration of the life-world (Sustainable, 2010).

According to the data of the Ministry of Environmental Protection and Regional Development, the non-renewable resources of Latvia are gypsum, limestone, dolomite, quartz sand, clay, sand and gravel. Based on the researched and evaluated stock of mineral resources and the extraction volume in 2013, gypsum will last for 50 years, sand - for 100 years, dolomite - for 210 years, clay - for 1130 years and limestone - for 1310 years. According to the Civil Law, in Latvia, the entrails of the earth, including mineral resources, belong to the land owners. However, to ensure sustainable use of resources, the state sets its conditions. Implementing the law "On the entrails of the earth", the law "On the evaluation of the impact on the environment" and other laws and regulations, a compromise between the interests of the land owners, the development needs and the environment protection requirements is achieved (Subterranean depths, 2019).

JSC "LATVIA'S STATE FORESTS" was founded in 1999, and it has set several strategic goals. One of the main strategic goals the company has set is to increase the long-term profit and to ensure positive cash flow from the operating activities, as well as it has set tasks related to public participation and collaboration in managing forests; to provide nature and recreation services from 
the forest eco-system. One of the sub-goals is development and maintenance of the infrastructure, i.e. building, repairing and maintaining forest roads (cleaning ditches, removing bushes).

JSC "LATVIA'S STATE FORESTS" manages the state-owned land in the amount of 1.62 million hectares, including 1.60 million hectares of forest land, out of which 1.39 million hectares are covered by forests (Latvian State Forests Forest..., 2018). LSF has the rights of possession based on: part 2 of Article 4 of Law on Forest, which provides that management and protection of the forest land written in the Land Register under the name of the country in the person of the Ministry of Agriculture and within the jurisdiction of the country and possessed by the country is performed by JSC "LATVIA'S STATE FORESTS" which has been established for governing and managing the state owned forest property (Law on Forest, 2000). The amount of wood output for the main cutting is determined by the order of the Cabinet of Ministers "On the maximum allowed volume for cutting trees" (2015), which is determined every five years. The currently actual period of the order is 2016-2020.

The company uses the stock of mineral resources it possesses for the construction of forest roads. Since 2002, JSC "LATVIA'S STATE FORESTS" has built approximately 5.6 thous. km of forest roads (FR) and in January 2018 the total length of FR reached 11.8 thous. km, 2.5 thous. of which are classified as no-surface roads (they cannot be used all year round, but just for a limited period of time). The total density of FR in the forests managed by JSC "LATVIA'S STATE FORESTS" is $1.06 \mathrm{~km}$ per 100 ha of a commercially usable forest (Latvia's Stare forests, 2018). To build FR the nonrenewable mineral resources of Latvia - sand, gravel, dolomite splinters - are used. JSC "LATVIA'S STATE FORESTS" extracts mineral resources: sand (S), sand and gravel (SG), sand, sand-gravel (SGS) (Seglins, V., 2007; Kurss, V., Stikule, A., 1997). The extraction of mineral resources takes place in all planning regions of Latvia: Latgale planning region (LPR); Vidzeme planning region (VPR); Riga planning region (RPR); Zemgale planning region (ZPR) and Kurzeme planning region (KPR). Extraction and use of mineral resources is linked with the building and maintenance of the forest road infrastructure, as well as selling to other interested persons (physical and legal). According to the available statistics, every year JSC "LATVIA'S STATE FORESTS" builds or reconstructs on average $318.3 \mathrm{~km}$ of forest roads (the average indicator in 2009 - 2017). Forest roads significantly ease managing of forest territories (preparing felling areas, cutting forests, transporting timber out of forests, planting and tending forests) and public availability of forests, develop new crossings of the traffic infrastructure in rural territories.

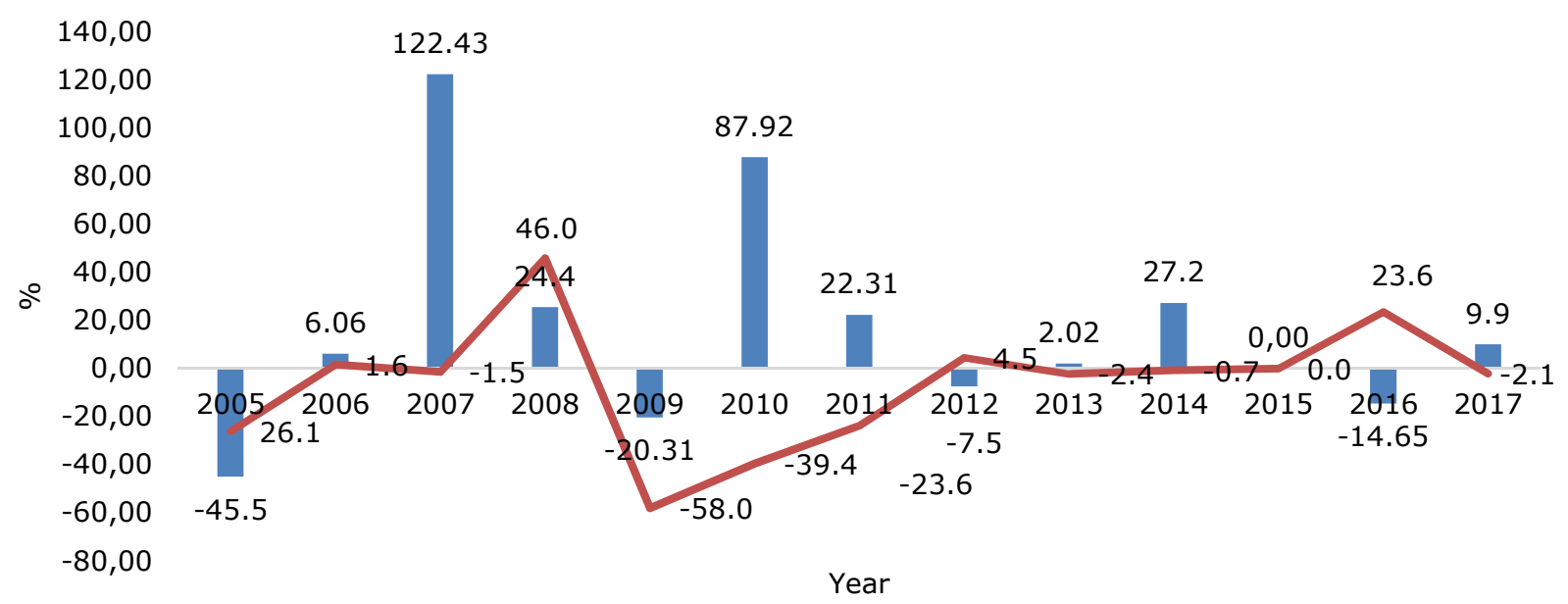

Profit after tax, base growth rate, \% Extraction of mineral resources, growth rate of base, \% 
Source: authors' created, based on JSC "LATVIA'S STATE FORESTS" and LEGMC databases

Fig. 2. The growth rate of JSC "LATVIA'S STATE FORESTS" profit after taxes and the base of extraction of mineral resources in $2005-2017, \%$

Comparing the growth rate of JSC "LATVIA'S STATE FORESTS" profit (after taxes) and the base extraction of mineral resources (base year 2015), it can be observed that the period of economic recession marks a new trend in resource extraction in the company: irrespective of the profit, the extraction of mineral resources is stable (see Figure 2).

The extraction and use of mineral resources for building, repairing and maintaining forest roads is the company's investment in the future, and it also eases the management and surveying of forest territories and the output of the forests. Evaluating the comparative indicators, it can be established that starting with 2010, the extraction of mineral resources is not closely linked with other economic indicators, that is extraction and use of resources do not affect directly the company's operations and the end result - obtaining profit.

A significant criterion in production of mineral resources is extraction of explored mineral resources, which is a guarantee that the acquired resources correspond to the needs of the company, to attaining particular goals. As provided by the Regulations of the Cabinet of Ministers (CM) "Procedure for extraction of mineral resources" (2006), mineral resources are divided into three categories. Licences for extraction are issued to extract " $\mathrm{A}$ " and " $\mathrm{N}$ " category mineral resources. To mine " $\mathrm{P}^{\prime}$ category mineral resources, licences are not issued (see Table 2).

Table 2

Categories of the stock of mineral resources

\begin{tabular}{|l|l|}
\hline \multicolumn{1}{|c|}{ Categories } & \multicolumn{1}{c|}{ Category characteristics } \\
\hline A category & Explored stock of mineral resources. \\
\hline $\mathbf{N}$ category & $\begin{array}{l}\text { Evaluated stock of mineral resources. The borders of the stock of mineral resources, the } \\
\text { deposit volume and structure are determined applying insufficient geological and } \\
\text { geophysical data which have been obtained searching for the resources or due to } \\
\text { insufficient geological exploration. The characteristics and quality of mineral resources, as } \\
\text { well as the engineering geological and hydrogeological conditions can be characterised by } \\
\text { analogy with the explored deposits found in the neighbourhood. }\end{array}$ \\
\hline P category & $\begin{array}{l}\text { Forecasted mineral resources. This category is assigned to mineral resources which are } \\
\text { calculated based on the results of geological mapping, search for mineral resources and } \\
\text { other geological research, as well as because in territories with favourable geological } \\
\text { circumstances the stock of the respective mineral resource acknowledged for genesis can } \\
\text { be evaluated by analogy with other explored deposits of the same genesis. }\end{array}$ \\
\hline Source: authors' created, based on the Regulations of the CM "Procedure for extraction of mineral resources"
\end{tabular}

The licence for extraction of mineral resources is issued to use " $A$ " and " $N$ " category stock, but extraction of " $\mathrm{N}$ " category mineral resources does not provide any guarantees that the use of resources is rational and serves its purposes. The data obtained from the evaluation of the extraction of JSC "LATVIA'S STATE FORESTS" mineral resources by categories and the planning regions are summarized in Table 3.

During thirteen years, the best extraction results are in RPR and VPR, the worst - in KPR because every year those mineral resources are extracted that have not been sufficiently explored and whose real value, actual stock and other geological criteria have not been clarified. 
Indications of the extraction of A category mineral resources against the total extraction in JSC "LATVIA'S STATE FORESTS" in 2005 - 2017, \%

\begin{tabular}{|c|c|c|c|c|c|c|c|c|c|c|c|c|c|}
\hline $\begin{array}{c}\text { Indicato } \\
\text { rs }\end{array}$ & $\begin{array}{l}\text { n̊ } \\
\text { 오 }\end{array}$ & 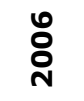 & 옹 & 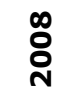 & $\begin{array}{l}\text { ㅇ } \\
\text { 유 }\end{array}$ & $\begin{array}{l}\circ \\
\text { - } \\
\text { N }\end{array}$ & ન્- & $\begin{array}{l}\text { N } \\
\text { 유 }\end{array}$ & $\stackrel{m}{\stackrel{m}{\circ}}$ & 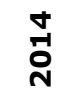 & 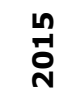 & $\begin{array}{l}0 \\
\stackrel{0}{1} \\
\stackrel{N}{N}\end{array}$ & 공 \\
\hline RPR & 93.7 & $\begin{array}{c}100 . \\
0\end{array}$ & $\begin{array}{c}100 . \\
0\end{array}$ & $\begin{array}{c}100 . \\
0\end{array}$ & 92.1 & $\begin{array}{c}100 . \\
0\end{array}$ & $\begin{array}{c}100 . \\
0\end{array}$ & $\begin{array}{c}100 . \\
0\end{array}$ & $\begin{array}{c}100 . \\
0\end{array}$ & $\begin{array}{c}100 . \\
0\end{array}$ & $\begin{array}{c}100 . \\
0\end{array}$ & $\begin{array}{c}100 . \\
0\end{array}$ & $\begin{array}{c}100 . \\
0\end{array}$ \\
\hline VPR & $\begin{array}{c}100 . \\
0\end{array}$ & 96.5 & $\begin{array}{c}100 . \\
0\end{array}$ & $\begin{array}{c}100 . \\
0\end{array}$ & $\begin{array}{c}100 . \\
0\end{array}$ & $\begin{array}{c}100 . \\
0\end{array}$ & $\begin{array}{c}100 . \\
0\end{array}$ & $\begin{array}{c}100 . \\
0\end{array}$ & 87.3 & 99.3 & 99.1 & 75.2 & 59.8 \\
\hline ZPR & 69.7 & 90.4 & 72.6 & 95.4 & 98.3 & 98.5 & 99.0 & 94.5 & 99.5 & 85.4 & 94.3 & 87.8 & 89.3 \\
\hline KPR & 99.8 & 95.1 & 86.1 & 94.6 & 91.1 & 98.3 & 100. & 99.8 & 98.6 & 67.9 & 76.3 & 82.4 & 40.8 \\
\hline LPR & 68.6 & 86.5 & 76.6 & 96.6 & 91 & 96.8 & 90.1 & 95.1 & 99.6 & 91.8 & 84.2 & $\begin{array}{c}100 . \\
0\end{array}$ & 97.4 \\
\hline
\end{tabular}

Source: authors' designed based on the LEGMC database

Evaluating the average indicators of the extraction of mineral resources during the thirteen-year period, the indicators of JSC "LATVIA'S STATE FORESTS" are better than those of other extractors of mineral resources in Latvia (Lazdins A., 2016). The calculated average indicator of the extraction of "A" category mineral resources against the total of mineral resources extracted in the company is $92 \%$. In 2017 there appear very low extraction indicators for " $A$ " category mineral resources in VPR and KPR because the mineral resources are extracted from new, partly explored extraction sites, as it can be seen in Table 3. Such an activity is legal, but it is not sustainable and does not correspond to the sustainability strategy of the European Union, nor the one of Latvia.

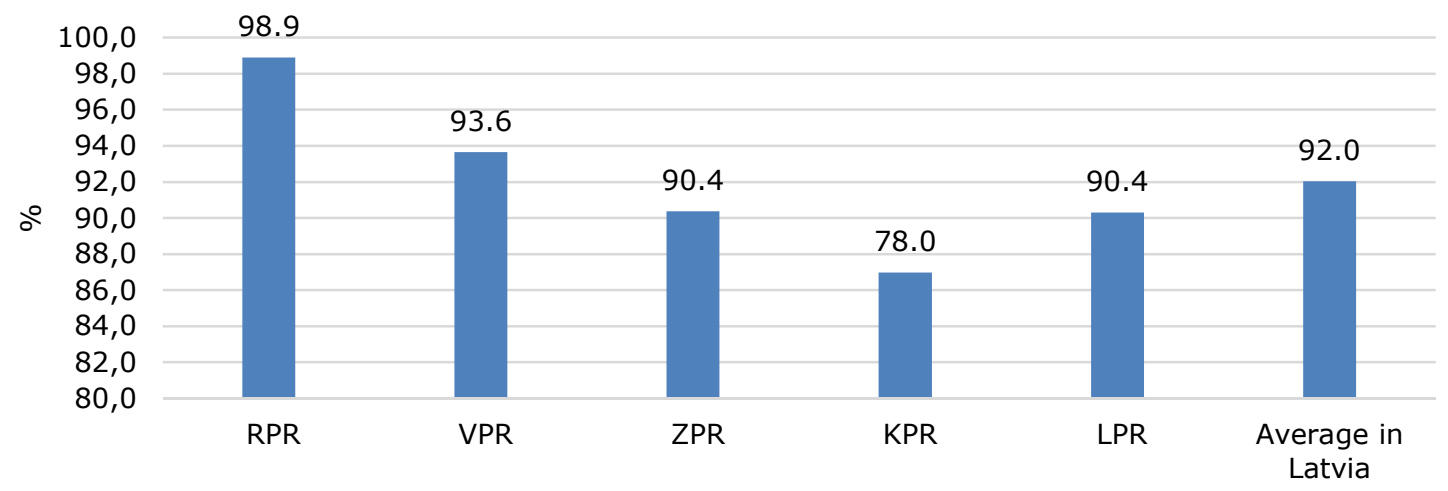

Planning regions of Latvia

Average figures

Source: authors' designed based on the LEGMC database

Fig. 3. Extraction of „A" category mineral resources in JSC „LATVIA'S STATE FORESTS" against the total extraction of mineral resources in $2005-2017, \%$

The best quality indicator for the extraction of mineral resources is in RPR, which is $98.9 \%$, but the worst one is in KPR - $87.0 \%$ (see Figure 3). Comparing the average indicator of extracting " $A$ " category mineral resources in Latvia with the extraction of " $A$ " category mineral resources by JSC "LATVIA'S STATE FORESTS", the indicators are worse in three regions - ZPR, KPR and LPR - $90.4 \%$, $87.0 \%$ and $90.3 \%$ respectively.

\section{Conclusions, proposals, recommendations}

1) Sustainability of mineral resources is linked with governing the reciprocity of economic, environmental and social processes, in which economic interests are to be made compatible with diverse processes. 
2) Sustainable management of mineral resources needs to be related to the notions of ecology and circular economy, in which an opinion exists that depletion of natural resources by itself undermines the economic growth and determines the need for the most efficient ways of using natural resources in business so that maintaining nature systems could support human life and welfare also in the future.

3) JSC "LATVIA'S STATE FORESTS" is one of the largest extractors and users of mineral resources in Latvia. Especially a lot of these resources are used in building, repairing and maintaining the infrastructure of forest roads.

4) In JSC "LATVIA'S STATE FORESTS" the extraction and use of mineral resources is not directly linked with the goals of production increase and economic growth but indicate to the sustainability of managing and surveying forests.

5) The performed calculations about the quality indicators of the extraction of mineral resources approve that $92.0 \%$ of these resources correspond to " $\mathrm{A}$ " category mineral resources which have been explored and approve the technical opportunities of their use.

6) In case of JSC "LATVIA'S STATE FORESTS" the problem is related to the places where mineral resources are extracted - on average $8 \%$ of the extracted mineral resources are obtained from new, partly explored deposits. Such an activity is legal, but it is not sustainable and does not correspond to the sustainability strategy of the European Union, nor the one of Latvia.

7) The research hypothesis is only partly validated - when building the forest infrastructure, JSC "LATVIA'S STATE FORESTS" partially implements sustainable management of mineral resources.

8) The recommendation to improve the situation is: for JSC "LATVIA'S STATE FORESTS" quality indicators of the extraction of "A" category mineral resources to achieve $100.0 \%$, the principles of sustainable management of mineral resources need to be included in the strategic goals of the company and implemented in real life to become the leading carrier of the idea of sustainable management of mineral resources in Latvia.

\section{Bibliography}

1. Brown, B., Hanson, M., Liverman, D., Meredith, R. (1987). Global Sustainability: Toward Definition. Environmental Management $11(6)$.

2. Darbibas parskati 2005 - 2017 gads (2019) (Activity reports 2005-2007). Retrieved: https://www.lvm.Iv/par-mums/skaitli-un-finanses/finanses. Access: 10.01.2019.

3. Derigo izraktenu (buvmaterialu izejvielu, kudras un dziedniecisko dunu) krajumu bilance par 2005. - 2017. gadu (Balance of stocks of mineral resources (raw materials, peat and healing sludge) 2005-2017) (2019). Retrieved: ttps://www.meteo.Iv/lapas/geologija/derigo-izraktenu-atradnu-registrs/derigo-izraktenukrajumu-bilance/derigo-izraktenu-krajumu-bilance?id=1472\&nid=659 pdf. Access: 10.01.2019.

4. Derigo izraktenu ieguves kartiba (Procedures for the extraction of mineral resources) (2012). MK noteikumi Nr. 570. Retrieved: https://likumi.lv/doc.php?id=251021 Access: 05.01.2019.

5. European Commission (2004). National Sustainable Development Strategies in the European Union. A first analysis by the European Commission. Commission Staff Working Document.

6. Kidd, C. (1992). The Evolution of Sustainability. Journal of Agricultural and Environmental Ethics 5.

7. Kurss, V., Stikule, A. (1997). Latvijas derigie izrakteni (Latvian mineral resources0. Riga: LU. 200 Ipp.

8. Latvian Environment, Geology and Meteorology Centre (LEGMC). Retrieved: https://www.meteo.Iv/en/lapas/about-centre?\&id=1473. Access: 10.01.2019.

9. Latvijas valsts mezi. Meza apsaimniekosanas plans 2018. - 2022. gadam (Latvian State Forests Forest Management Plan 2018- 2022) (2018). Publiskā dala. Retrieved: https://www.Ivm.Iv/images/lvm/sabiedriba i/meza_apsaimniekosana/meza-apsaimniekosanas-plana-publiska-dala.pdf. Access: 10.01.2019.

10. Lazdins, A. (2016). Development of mineral resource market in Latvian's regions (Summary of the Doctoral Thesis for the Degree Dr.oec.). Jelgava. 117 pp.

11. Meza likums (Law on Forests) (2000). LR likums: saeimā pienemts 24.02.2000. Retrieved: https://likumi.Iv/doc.php?id=2825. Access: 10.01.2019. 
12. Par ietekmes uz vidi novertejumu (On Environmental Impact Assessment). LR likums: saeima pienemts 14.10.1998. Retrieved: https://likumi.Iv/doc.php?id=51522. Access: 10.01.2019.

13. Par koku cirsanas maksimali pielaujamo apjomu 2016.-2020. gadam (On tree felling ceilings for 2016-2020) (2015). MK rikojums Nr 718. Retrieved: https://likumi.Iv/ta/id/277848-par-koku-cirsanas-maksimalipielaujamo-apjomu-2016-2020-gadam.

14. Par zemes dzilem (Law on Subterranean Depths). LR likums, saeima pienemts: 02.05.1996. Retrieved:https://likumi.Iv/doc.php?id=40249. Access: 10.01.2019.

15. Portney, K. (2015). Sustainability. Cambridge, Massachusetts: The MIT Press.

16. Robinson, J., George, F., Russel, L., Lerner, S. (1990). Defining a Sustainable Society: Values, Principles, and Definitions. Alternatives 17 (2).

17. Roosa, S. (2010). Sustainable Development Handbook (Vol. 2nd ed). Lilburn, GA: Fairmont Press.

18. Seglins, V. (2007). Zemes dzilu resursi (Resources of subterranean depths). Riga: Izdevnieciba RaKa. 380 Ipp.

19.Sustainable Development Strategy of Latvia until 2030 (2010). Retrieved:www.varam.gov.Iv/in_site/tools/d ownload.php?file...2030...en. Access: 10.01.2019.

20. The Brundtland Report "Our Common Future". (1987). Report of the World Commission on Environment and Development: Our Common Future. Transmitted to the General Assembly as an Annex to document A/42/427 - Development and International Co-operation: Environment. Retrieved: http://www.undocuments.net/ocf-02.htm\#I, Access: 10.01.2019.

21.Zemes dziles (Subterranean depths) (b.g.). VARAM. Pieejams: http://www.varam.gov.lv/lat/darbibas_veidi/ zemes_dziles/. Access: 10.01.2019. 